\title{
КОНЦЕПТУАЛІЗАЦІЯ ДИСЦИПЛІНАРНО-МЕТОДОЛОГІЧНОЇ МАТРИЦІ РОЗВИТКУ ЗДОРОВ'ЯЗБЕРЕЖУВАЛЬНОӤ КОМПЕТЕНТНОСТІ ВЧИТЕЛЯ ФІЗИЧНОӤ КУЛЬТУРИ В УМОВАХ ПІСЛЯДИПЛОМНОЇ ОСВІТИ
}

В статті представляється методологічна розробка дисциплінарно-методологічної матриці розвитку здоров'язбережувальної компетентності вчителя фізичної культури в умовах післядипломної освіти, яка є рівневою та інтенціональною системою навчальних дисциплін та актуальних проблем. На основі трансферу медччнх знань в ціннісно-смислових і методологічних рамках вказаної матриці нами репрезентуються нові методичні (чи дисциилінарні) напрями: "Патопедагогіка" ("Маргінальна педагогіка"), "Пропедевтика здоров'я і профілактики", "Збереження здоров 'я і профілактика".

Зазначені напрями є гуманітарною і педагогічною інтерпретацією традиційних медичних дисциилінарних напрямів.

Ключові слова: здоров'язбережувальна компетентність вчителя фізичної культури, методологія, методика, трансфер знань, дисциплінарно-методологічна матриця, дисциплінарна структура, освітня раціональність, парадигма.

Doctrina multiplex, veritas una. Мудрість в тому, щцбб знати все як одне. Гераклім

Постановка проблеми. В освітньому процесі у вищих навчальних закладах формування компетентностей реалізується на основі регламентованих систем навчальних дисциплін, в яких відображені традиції і специфіка професії та проявлена парадигма сучасної науки. В післядипломній освіті така регламентація відсутня, що відкриває можливості для творчості, інтерпретацій та створення нових форматів і підходів до формування навчальних програм. При цьому в післядипломній освіті використовується усталена і досить ефективна структура формування навчальних планів та програм. В рамках цієї структури визначені як обов'язкові гуманітарний, професійний, інноваційний та інші блоки, які варіативно заповнюються відповідними темами, курсами. Ця структура має тільки частково дисциплінарний характер. Об'єктивно вона $є$ змішаною - проблемно-тематично-дисциплінарною і завдяки своїй варіативності відповідає реальним запитам освітян.

При формуванні чи удосконаленні таких складних за змістовним наповненням компетентностей як здоров'язбережувальна, постає методологічно значима проблема підбору тем і дисциплін та формування навчальних програм. Загалом це реалізується шляхом використання проблемного, цільового і потребнісного принципів. Центральним аспектом є орієнтація на результати навчання [1: 17-26; 67-69]. Це відповідає сучасним європоцентричним тенденціям, а також є співвідносним до психофізіологічних уявлень про навчання як процес формування функціональних систем. Відповідно до вчення П. Анохіна про функціональні системи, вони формуються на основі мети і результату. Таким чином орієнтація не тільки на мету але і на результат відповідає психофізіологічній природі людини, а таке навчання $€$ природовідповідним. При розробці навчальних програм нами враховуються також ресурси [1: 17-26; 6769] і запити слухачів [1: 17-26; 67-69]. Для післядипломної освіти, на даний час, такі критерії як можливості працевлаштування [1:17-26; 67-69] і подальше навчання вчителя мають значно менше значення, але також нами беруться до уваги. Визначальними критеріями є нормативні акти і стандарти вищої освіти [1: 58-59] та врахування європейських і українських тенденцій розвитку.

При цьому залишається відкритими методологічні, педагогічно-організаційні та методичні питання необхідності формування таких систем дисциплін (дисциплінарних основ чи матриць) і тем, які можуть забезпечити розвиток достатнього інтелектуального, світоглядно-методологічного, герменевтичного, аксіологічного, екзистенційного та культурно-професійного потенціалів вчителя. Це включає розвиток у педагога здатностей до узагальнень, аналізу, концептуалізації, інтерпретацій, експертних розумінь та панорамних і цілісних візій теоретичного базису професійної діяльності та практик збереження здоров'я, а також вміння діяти самостійно та ін.

В даному напрямі актуальним $є$ питання використання в післядипломній освіті фундаменталізації, яка спрямована на розвиток системних, узагальнюючих, концептуальних, фундаментальних, професійносвітоглядних i науково-світоглядних знань та системного мислення. Фундаменталізація $\epsilon$ методологічною і навчальною передумовами розвитку професійної та інтелектуально-професійної 
"глибини", "наповненості", інтелектуально-особистісного потенціалу, професіоналізації вчителя і самоповаги, а також формування його професійної суб'єктності. На вихідному методологічному рівні актуальним $\epsilon$ визначення базисного набору дисциплін, напрямів, тем і проблем, які $є$ дисциплінарною основою навчальних програм.

Важливим в методологічному плані $\epsilon$ те, що саме дисциплінарно-наукові напрями розкривають панораму їм притаманних візій, цінностей, феноменів, закономірностей, інтерпретацій, методів. Кожна навчальна дисципліна - це вікно у свій світ, в свою особливу "реальність" та специфічну "когнітивність" i онтологію, це шлях до певних розумінь і знань та відповідна система інтелектуальних стереотипів і інструментів. Тобто це онтологічний (буттєвий), гносеологічний (в розумінні пізнавальний), герменевтичний (розуміння та інтерпретація), праксеологічний (в розумінні практик і технологій) виміри культурно-освітнього і інтелектуально буття, "входячи" в яке вчитель розвивається, трансформуючись в інтелектуальну особистість, а також підвищує свій професійний рівень та стає компетентним.

Сума, а точніше "пізнавально-ціннісна" система (матриця) певної конкретної дисципліни, розкриває світ як багатовимірний, варіативний і формує професійний інтелект та визначає шляхи до оволодіння практиками і технологіями збереження здоров'я. Актуальною складовою нашої проблематизації $\epsilon$ профілактика гострої кардіологічної патології [2], ризиком виникнення якої $є$ рухова активність. Для того, щоб вчитель міг оволодіти профілактичними і діагностичними навичками, розуміннями, візіями та технологіями в нього має бути сформований певний рівень фундаментальних знань. Така підготовка реалізується на основі використання системи традиційних дисциплін про людину і їі здоров’я. До цих дисциплін відносяться анатомія, фізіологія, патологія та ін.

На основі вищезазначеного аналізу значимості "дисциплінарного виміру" для формування методології і методики розвитку здоров'язбережувальної компетентності вчителя фізичної культури в умовах післядипломної освіти нами визначається як актуальна, проблема необхідності розробки "методологічнодисциплінарної матриці", в структурі якої має бути відображена системність, фундаментальність, трансдисциплінарна і міждисциплінарна специфіки та навчально-методичні особливості інтегративного i специфікованого використання науково-дисциплінарних, проблемних, тематичних та практичних напрямів. Недостатне висвітлення вказаної проблеми в науковій педагогічній літературі визначає необхідність конструювання методологічно-дисциплінарної матриці, що нами розглядається як методологічна умова системного, інтегративного i ефективного застосування різних науководисциплінарних напрямів як усталених, так і нових, формування яких залежить від практичних та навчально-методичних запитів i сумарно спрямовується на розвиток здоров'язбережувальної компетентності вчителя фізичної культури, а також $\epsilon$ значимим у вирішені актуальних питань збереження життя і здоров'я дітей в умовах освітнього процесу. Сукупно вказані аргументи репрезентують дану проблему як актуальну та розкривають необхідність проведення відповідного дослідження.

Аналіз останніх досліджень і публікацій. Методологічні та методичні аспекти проблематики збереження здоров'я в умовах освітнього процесу та формування здорового способу життя розкриті в роботах О. Аксьонової, Т. Андрющенка, Г. Апанасенка, Н. Башавець, Т. Бережної, І. Беха, Ю. Бойчука, Т. Бойченко, О. Вознюка, С. Гаркуші, М. Гончаренко, М. Гриньової, Ю. Драгньова, Л. Дудорової, О. Сжової, С. Срмакова, Г. Жарої, А. Жиденко, Г. Мешко, М. Носко, Л. Омельченка, В. Омельяненка, В. Оржеговської, С. Панченко, С. Страшка, Г. Тимченко, В. Смоляра, В. Солнцева, Н. Соловьйова, Л. Тихомирова, О. Ужеліна. Актуальні методологічні і технологічні питання валеології представлені в дослідженнях В. Алябьєва, Г. Апанасенка, Т. Бойченко, І. Брахмана, Е. Булича., Н. Вайнера, О. Гладощука, М. Гончаренко, Г. Грибана, І. Гундарова, Т. Камнєва, О. Качана, I. Корженко, М. Костикова, І. Миргорода, О. Міхільова, І. Муравйова, Е. Нікитенка, С. Присяжнюка, І. Поташнюка, Г. Хомутова, Н. Ярошенко. Проблематика профілактики гострої кардіологічної патології під час занять фізичною культурою і юнацьким спортом висвітлена в роботах В. Будзини, Д. Окунева, О. Раганова, О. Рябухи, А. Терехова, В. Федорця [1], S. Van Camp, C. Bloor, F. Mueller, R. Cantu, H. Olson, B. Maron, $\mathrm{N}$. Estes та інших дослідників. При формуванні методології нашої педагогічної системи ми спираємося на методологічні і методичні розробки вище вказаних дослідників.

Для розробки "дисциплінарно-проблемної матриці" здоров'язбережувальної компетентності вчителя фізичної культури ми використали поняття парадигми і дисциплінарної матриці, які були введені в науку Томасом Семюелем Куном (англ. Thomas Samuel Kuhn) [3]. Поняття парадигми відображає не тільки об'єктивізовані і концептуальні аспекти науки, а перш за все, інтегративно і цілісно розкриває іï світоглядний, ціннісний, символічний, ідеологічний, метафізичний, соціокультурний, темпоральноісторичний $\mathrm{i}$ комунікативний виміри. Відповідно в "дисциплінарно-проблемній матриці", яка розробляється нами, відображене сучасне парадигмально узагальнене постнекласичне розуміння здоров'я як "благополуччя", "екзистенційної наповненості", "антропологічного феномену" та ін. Саме через антропологічно [2; 4] і гуманітарно [4] орієнтовані розуміння педагогіки і феномену здоров'я, а також шляхом використання герменевтичних [5: 192-210], комунікативних [5: 146-164], аксіологічних, 
компетентнісних [1] і трансдисциплінарних [2; 4] візій та підходів, розкриваються визначальні аспекти постнекласичної парадигми та специфіка освітньої раціональності [5], які є науково-практичними і світоглядно-аксіологічними орієнтирами при розробці нашої методології та методик, практик i технологій.

Розробка даної дисциплінарно-методологічної матриці, окрім репрезентації актуальних проблем і тем, розкриває дисциплінарну організацію і епістеміологічну структуру певного "фрагменту" сучасної науки і соціо-культурно орієнтованих практик збереження здоров'я. Нами також робиться спроба антропологічно і практично орієнтовано репрезентувати феноменологію, онтологію, аксіологію та людиномірну i освітньо орієтовану специфіку виокремлених антропологічно спрямованих дисциплінарних і проблемних напрямів, а також висвітлити їх навчальну, культурно-освітню цілісність та розкрити шляхи для практичного розуміння їх предметного [5: 123-128] знання. В даному аспекті наші методологічні розробки базуються на методологічно-світоглядних ідеях і узагальненнях дисциплінарної структури науки О. Огурцова [6]. Дисциплінарну організацію науки досліджували І. Блауберг, П. Бордье, Б. Грязнов, И. Лакатос, І. Касавін, Б. Кедров, Д. Крейн, М. Малкей, Н. Маллінз, Л. Мікешина, Т. Парсонс, В. Стьопін, Р. Уітлі, Б. Юдін та ін.

Філософською i методологічною основою наших парадигмально орієнтованих осмислень i узагальнень дисциплінарних напрямів, спрямованих на формування здоров'язбережувальної компетентності вчителя фізичної культури є антропоцентричні, феноменологічні, екзистенційні та освітньо-філософські ідеї В. Кременя [7], І. Зязюна, В. Сухомлинського, О. Дольської [5], О. Больнова (O. Bollnow) [8], І. Дерболава (I. Derdolav), М. Лангевельда (M. Langeveld), В. Лоха (W. Loch), К. Роджерса (C. Rogers), Г. Рота (H. Roth), М. Фуко (M. Foucault), В. Франкла (V. Frankl), К. Ясперса (K. Jaspers), М. Шелера (M. Scheler). До дисциплінарно-методологічної матриці здоров'язбережувальної компетентності близьким (майже аналогом) є усталене поняття міждисииплінарної матриці, яке існує в соціології, і представляє собою об'єднання (точніше систему) певних дисциплін, які використовуються для соціологічних досліджень.

Дисциплінарно-методологічна матриця розробляється нами на основі методологічних і методичноціннісних орієнтирів, якими представляються інноваційні, креативні, студентоцентричні та євроінтеграційні ідеї, підходи, візії, досвіди і рекомендації, розроблені співробітниками Інституту вищої освіти Національної академії педагогічних наук України. Перш за все, ми використовуємо концепти і рекомендації, висвітлені в роботах [1] В. Лугового, Ж. Таланової, О. Слюсаренко, В. Захарченка, Ю. Рашкевича. Розробки цих дослідників, в яких розкриті європоцентричні стратегії реформування української освіти, є визначальними при формуванні навчальних освітніх програм [1]. В дослідженнях вказаних авторів відображено осмислення європейського досвіду, який сформувався при реалізації міжнародного проекту Tuning educational structures in Europe, TUNING (Гармонізація освітніх структур у Європі) [1]. Метою проекту TUNING була імплементація ідей та підходів Болонського процесу. Актуальними в даному напрямі є також методичні напрацювання дослідників Ю. Холіна, С. Кравцова, Т. Маркова з Харьківського національного університету імені В. Н. Каразіна.

Метою нашого дослідження була розробка дисииплінарно-методологічної матриці (структури), яка репрезентується як актуальна складова епістеміологічної, методологічної, методичної, змістовної і навчальної основ розвитку здоров'язбережувальної компетентності вчителя фізичної культури в умовах післядипломної освіти. Реалізація вказаної мети включала в себе аналіз значимих дисциплінарних i проблемних напрямів; осмислення проблематики збереження життя і здоров'я учнів, питань норми, патології, інклюзії та важливості діагностичних методик і технологій; трансферу знань, методологій, стратегій і цінностей; актуалізацію питання освітньої раціональності. Значимим завданням при розробці даної дисциплінарно-методичної матриці було питання демаркації наукових і квазінаукових, "народних" (в розумінні етнонаукових) та шарлатанських знань, уявлень і практик збереження здоров’я.

Виклад основного матеріалу. Мейстримом здоров'язбержувальної діяльності вчителя фізичної культури, окрім розвитку здорового способу життя, є профілактика і корекція порушень здоров'я, та найголовніше, мінімізація (і виключення) загроз життю [2] учнів. Ефективно це може бути реалізовано, перш за все, на основі виділення діагностичного етапу i / чи компоненту як значимого в освітніх технологіях і практиках збереження здоров'я, а також як обов'язкового інтелектуального навичку i системи стратегій, сформованих в структурі здоров'язбержувальної компетентності вчителя фізичної культури. Технологічно значимим $є$ те, що педагог має здійснювати діагностичний контроль стану здоров'я учнів в динаміці, в процесі проведення занять, в режимі реального часу (лат. Hic et nunc принцип тут і тепер), що включає аналіз наявного стану учнів та проекцію вчителем своїх діагностичних візій в майбутнє. В здоров'язбережувальній діяльності діагностика є найбільш значимою, первинною і найскладнішою. На іiі основі визначаються подальші шляхи діяльності і конкретні дії педагога, які $є$ варіативними та часто такими, що виключають одне одного: корекція, надання допомоги, зміна тренувального режиму чи не втручання, тощо. Тому на основі осмислення значимості діагностичного аспекту в збереженні життя та здоров'я учнів в здоров'язбережувальних технологіях і практиках ми 
виділяємо діагностичні $i$ прогностичні, які мають свою особливу методологічну, інтелектуальну, інтелектуально-ціннісну та інтуїтивно-чутливу природу.

Можна зауважити: "Чому це важливо?". Впровадимо освітні здоров’язбережувальні технології і всі будуть здорові! Така думка має певну істинність, але лише частково, тому що кожен організм зреагує на здоров’язбережувальні технології індивідуально, а той парадоксально. Крім того, майже всі технології на заняттях 3 фізичної культури формуються на основі рухової активності, яка потенційно $є$ умовою виникнення ризиків [2]. Тому саме наявність системних ризиків, які створюються руховою активністю а priori визначає діагностичні здоров'язбережувальні технології $i$ практики як актуальні, i такі, які потребують активної розробки. Вказані ризики також $є$ освітньою умовою актуалізації (а також відновлення, поглиблення і формування) у вчителя фундаментальних і спеціальних знань про людину. Для того, щоб впровадити "реальні" діагностичні, технології і підходи, необхідно сформувати систему методологічних, методичних та інтелектуально-ціннісних умов, серед яких, як провідний напрям, ми виділяємо трансфер медичних [8; 9] і частково психологічних знань, стратегій, цінностей і тактик. Такий трансфер потрібно здійснювати в рамках певних дисциплінарних і проблемних напрямів. Важливість трансферу та інтеграції вказаних традицій обумовлена тим, що тільки в медицині вказані діагностичні методики і технології є розробленими, об'єктивізованими і апробованими. Можливий інший шлях, який існує тепер. Це відносно проста практика використання рецептурних знань та "зрозумілих", простих рекомендацій.

На тепер до складу підготовки вчителя фізичної культури входять науки, які формують фундаментальні знання про людину. Це такі дисципліни як анатомія, гістологія, фізіологія, біохімія. Викладається також практично орієнтована дисципліна - валеологія. Разом з тим, знання, отримані в рамках вказаних дисциплін, представляються досить схематичними, ідеалізованим та не достатньо адаптованими до проблематики профілактики та корекції певних порушень і питання збереження життя, яка в професійній діяльності вчителя фізичної культури є визначальною. Це зрозуміло, тому що представлені дисципліни, окрім валеології, превентивної педагогіки $є$ теоретичними. Тому нами використовується "Валеологія" для розвитку здорового способу життя та формування ціннісного ставлення до здоров'я. Важливою практично орієнтованою дисципліною є "Превентивна педагогіка".

В умовах післядипломної освіти існує значно більше можливостей для впровадження інноваційних і проблемно орієнтованих підходів, систем, методик і формування навчальних програм. Відносно даної проблематики, вказані інноваційні тенденції реалізуються нами шляхом трансферу медичних, гігієнічних i психологічних знань. Нами сформована "Антропологічна модель здоров'язбережувальної компетентності вчителя фізичної культури" [4] та апробована педагогічна система розвитку вказаної компетентності, в розробці якої враховані значимі особливості дисциплінарно-методологічних стратегій, які $€$ характерними для медичної традиції та превентивної педагогіки. Специфічна дисциплінарнометодологічна структура, що $є$ базовою і традиційною в підготовці лікарів, побудована на основі виділеної ще Арістотелем [9; 10] схеми "ерishtime - tecnhe" (знання - техніка, мистецтво), яка в рамках нашої методологічної системи розширено інтерпретується в форматі методологічних стратегій: "теорія практика", "фундаменталізація - технологізація", "схематичне - феноменологічне".

Теоретичний блок у даній дисциплінарній структурі складають такі дисципліни, як анатомія, гістологія, ембріологія, біологія людини, і біохімія, які є "чистою" теорією, і можуть розглядатися як "epishtima", в рамках яких людина представляється досить ідеалізовано, та певною мірою, ейдетично. Techne, яке розуміється як практика, технологія, мистецтво, представлено розмаїттям клінічних (лікувальних, практичних) дисциплін адаптованих до лікування. Крім того, існує виокремлено поняття практики i володіння певною медичною технологією, а також перехідна ланка між теорією i практичними дисциплінами - пропедевтика.

Інтерпретуючи схему Аристотеля [9; 10] "еріstima - tecnhe" в рамках нашої методології, ми говоримо про такі значимі в їі складі методологічно-проблемні осі (напрями) як: "ідеальне - реальне", "загальне специфіковане (конкретизоване)", "схематичне, ідеалізоване - феноменологічне, реальне", "цінності як ідеї - цінності як ситуації, події, проблеми, феномени" та ін. Актуалізація вказаних методологічнопроблемних стратегій (напрямів) сприяє розкриттю, осмисленню та репрезентації значимих аспектів проблематики збереження здоров'я, що $є$ важливим як для медичних, так i для освітніх практик i технологій. В освітній практиці існує подібний поділ. Теоретичними (epishtime) предметами також витупають анатомія, фізіологія, а превентивна педагогіка і валеологія мають технологічне (techne) спрямування.

Розглядаючи надалі медичний формат дисциплінарно-методологічних схем і стратегій підготовки фахівця, в яких відображено ідеї "еріstima - tecnhe" і "теорія - практики, технології", ми визначаємо наявність в них значимих і системоформувальних проміжних складових між крайніми полюсами. Тобто "проміжок" [10] між "еріstima" i "tecnhe" $\epsilon$ розробленим i "заповненим". Тому повністю медична дисциплінарно-методологічна схема має такий вигляд: 
I. Теоретичні дисципліни. Вони розкривають панораму загальних ідеалізованих, нормативних, схематичних та частково феноменологічних уявлень і знань про людину. Це такі науки, як: анатомія, гістологія, ембріологія, фізіологія, біохімія, біологія людини, психологія (має значно ширший формат).

II. Теоретичні і практично орієнтовані дисципліни. Вони формують уявлення про людину в системах взаємодії: "адаптація - дезадаптація", "норма - патологія", "нормативність - крайові, екстремальні стани і стреси", "людина - середовище", "ідеальне, нормативне - змінене" та ін. До цих дисциплін відносяться: "Патологічна анатомія", "Патологічна фізіологія", "Фармакологія", та ін.

III. Практично і методично орієнтовані узагальнюючі дисципліни, які також мають свою теоретичну базу та формуються на основі фундаментальних (теоретичних) знань. Основна з них це "Пропедевтика" (грец. propaidéū̄ - вступ, попереднє навчання) (вступ до конкретної науки чи діяльності) терапії, хірургії, психіатрії та ін. Пропедевтика формує загальні і цілісні знання та уявлення, а також розвиває ставлення, інтенції, цінності, розкриваючи феномен людини в нормативних, крайових і патологічних станах. Ця дисципліна висвітлює основи діагностики, класифікації основних порушень і шляхи та стратегії профілактичних та лікувальних впливів.

IV. Практично орієнтовані і специфіковані (конкретизовані) та проблемно спрямовані дисципліни, які сформовані на основі своєї теоретичної бази та фундаментальних (теоретичних) знань пропедевтики, патології, а також через осмислення відповідних практик. Це клінічні дисципліни, які формують конкретизовані (специфіковані), феноменологічно, практично і технологічно орієнтовані знання, вміння, навички, розуміння, інтерпретації, інтенції, ставлення, ментально-ціннісні стереотипи, тощо. Наприклад, терапія, хірургія, ендокринологія тощо.

V. Практична діяльність, яка включає практики і технології. Це загальні, спеціальні і проблемно орієнтовані практики.

Ефективність даної дисциплінарно-методологічної моделі підтверджена часом. По іншому і не можливо навчитися медицині. Проводячи епістеміологічний аналіз вказаної схеми, ми можемо відмітити наявність кількох етапів у переході від теорії до практики і технологій. Кожен з цих етапів має свої якісні характеристики, які роблять наявність етапності обов'язковою. Відповідно кожен з зазначених етапів (i/чи рівнів) (а це системи окремих дисциплін), будучи відносно автономним і завершеним, відображають способи проблематизації, розумінь та інтерпретацій, а також формують і специфікують (конкретизують) відповідні знання, навички, стратегії, тактики. Крім того, формування зазначених складових професійної компетентності лікаря (знань, навичок, візій, цінностей тощо) і їі в цілому $\epsilon$ неможливим при виключенні (відсутності) якогось із вказаних вище п'яти "дисциплінарнометодологічних" етапів.

Наступними важливим практично орієнтованим аспектом даної схеми є трансфер знань між різними рівнями дисциплінарно-методологічної моделі. Це включає розгляд певних феноменів і проблем в різних контекстах - контекстуалізацію. Крім того, при цьому здійснюється інтеграція, аксіологізація, специфікація і практична та технологічна орієнтація не тільки знань, але й мислення, цінностей і візій фахівця. При "проходженні" фахівця через вказані етапи в нього формуються не тільки певні знання, розуміння, цінності, ставлення, але й трансформуються вже наявні. Важливим у цій складній багаторівневій підготовці $є$ також формування особистісних знань, ціннісних орієнтацій, ставлень, установок і візій. Таким чином, представлена схема системно впливає і на професійну суб'єктність майбутнього фахівця. Як говорили в давнину - Discere mutari est (Вчитися означає змінюватися).

В педагогічній теорії і практиках збереження здоров'я "плавний", логічний, системний перехід між epistima i tecnhe майже відсутній. Epistima i tecnhe функціонують як відносно відокремлені епістеміологічні, ціннісні, світоглядні, методологічні і навчальні системи. Це, на нашу думку, є однією 3 методологічних умов не достатньої ефективності і деякої "штучності" та "загальності" педагогічних практик збереження здоров'я, а також відповідного дещо формального та "ідеалізованого" характеру здоров'язбережувальних компетентностей. Звичайно, що для вчителів не потрібна така спеціальна підготовка і відповідний об'єм знань як для лікарів. Ми і не ставимо таке питання. Ідеєю є необхідність формування фрагментарних i специфікованих за змістовною наповненістю професійних здоров'язбережувальних знань, які є одночасно цілісними і структурованими за смисловою структурою (смисловим наповненням). Відповідно актуальним представляється також розвиток у педагога панорамних, інтегративних, практично орієнтованих і специфікованих професійних уявлень, візій та знань про здоров’я, основні ризики і патології, які реально зустрічаються в професійній діяльності вчителя фізичної культури. I безумовно важливим $\epsilon$ налагодити "місток", а точніше ціле "епістеміологічне буття", між педагогічними здоров'язбережувальними episteme i techne, між теорією і практикою, ідеальним і реальним, схематичним і феноменологічним. Питання ставиться не стільки про збільшення обсягу знань, а про їх специфікацію, систематизацію, феноменологізацію, практичну і технологічну спрямованість, ціннісний i гуманістичний виміри. Тому ми, рецептуючи основні методологічні аспекти зазначеної вище медичної дисциплінарно-методологічної стратегії, трансформуємо їі в нашу модель, яку називаємо дисциплінарно-методологічною матрищею. 
Таким чином, ми формуємо концепт дисииплінарно-методологічної матрииі здоров'язбережувальної компетентності вчителя фізичної культури. Вказана матриця $\epsilon$ цільовим, системним і антропологічноціннісним об'єднанням навчальних дисциплін, тем та проблемних напрямів, що сукупно формують методологічну, епістеміологічно-ціннісну, змістовну, навчально-методичну та практично орієнтовану дисциплінарно-методологічну систему, спрямовану на розвиток здоров'язбережувальної компетентності. Дисциплінарно-методологічна матриця відрізняється від близьких за смислом переліків навчальних дисциплін наступними особливостями: вона $\epsilon$, окрім цільового, також культурно, антропологічноціннісним, проблемно, трансдисциплінарно і міждисциплінарно орієнтованим об'єднанням дисциплін; в ній виділені, окрім навчальних дисциплін, як значимі певні теми (наприклад профілактика раптової серцевої смерті) і проблемні напрями (наприклад проблема профілактики травм); вона формує методологічні передумови "створення", відповідно до мети, стратегій і специфіки певних методично і практично орієнтованих рівнів та "методичних дисциплін" (чи "дисциплінарно-методичних напрямів"); сприяє трансферу і інтеграції методології, знань, цінностей і візій; в ній актуалізовані рівневість структури, яка в значній мірі задає послідовність та особливості розвитку здоров'язбережувальної компетентності; завдяки цій структурі існує епістеміологічна основа для аналізу впливів на фахівця не тільки окремих дисциплін, а сукупно дії виокремлених рівнів і матриці в цілому; актуальним аспектом $\epsilon$ формування в раціональних і смислових рамках даної матриці специфічної освітньої раціональності яка середовищно (в рамках освітнього середовища) розглядається як інтелектуально-ціннісно-смислове поле діяльності фахівця, а в особистісному вимірі репрезентується як певна метаякість, специфіка інтелекту вчителя та особливість його раціональної професійної поведінки; з метою гуманізації актуалізується ідея інтеграції наукової, професійної та культурної складових вказаних дисциплін на основі антропологічноціннісної орієнтації, що формується через розкриття освітньої раціональності; сукупність дисциплін розглядається як цілісна методологічна, методична, навчальна і епістеміологічна система, яка, окрім формування здоров'язбережувальної компетентності та інтелекту, впливає на професійну суб'єктність фахівця та сприяє створенню гуманістично орієнтованого і інтелектуалізованого освітнього середовища та ін.

Смислові, знаннєві та інтенціональні рамки дисциплінарно-методологічної матриці здоров'язбережувальної компетенності розглядаються як системні передумови активного трансферу методології, знань, цінностей і візій, що відповідно визначає необхідність організації наявних знань та практик в нові та практично орієнтовані науково-дисциплінарні напрями (чи "методичні дисципліни"). На даний час їх можна розглядати поки, що частково як методологічні, та переважно як дисииплінарнометодичні напрями ("методичні дисципліни"), основною метою яких $є$ ефективний розвиток здоров'язбережувальної компетентності вчителя фізичної культури в умовах післядипломної освіти. Розкриваючи деякі актуальні характеристики, представимо зазначену нами дисциплінарнометодологічну матрицю розвитку здоров'язбережувальної компетентності вчителя фізичної культури, яка складається з п’яти блоків (рівнів).

I. Рівень теоретичних дисииплін про людину як виокремлений феномен. В рамках зазначених наук людина розглядається відносно виокремлено та ідеалізовано (окрім психології і біології), "ейдетично". Цим дисциплінам відповідає "ідеальний" концепт "Людина". Науки, які формують цей дисциплінарнометодологічний рівень, представлені анатомією, гістологією, ембріологією, фізіологією, біохімією, біологією людини, психологією (ця наука має значно ширший формат). Вказані дисципліни репрезентують систему загальних, нормативних, ідеалізованих, схематичних, фундаментальних уявлень i знань про людину. Тобто цей блок залишається майже без змін. Він таким існував і раніше.

Крім традиційних дисциплін, ми актуалізуємо необхідність використання біомеханіки і кінезіології як наук, необхідних для розуміння природи руху. Ми акцентуємо увагу також на необхідності актуалізації феноменологічних, ціннісних, екзистенційних, людиномірних, гуманістичних аспектів при викладанні вказаних дисциплін, а також ставимо питання про важливість впровадження такої дисципліни, як антропологія (педагогічна, психологічна, фізична, філософська). Важливим є також налагодження міждисциплінарних зв'язків між дисциплінами даного рівня і гуманітарними науками - педагогікою, філософією, етикою, естетикою та мистецтвом.

II. Рівень теоретично і практично орієнтованих дисциплін про людину, де вона розглядається 6 контексті патологічних змін і взаємодії з середовищем. В цьому випадку нами репрезентується нова дисципліна, яку ми на даному рівні визначаємо як основну. Це "методична дисципліна" "Патопедагогіка" (чи "Маргінальна педагогіка"). Вказана дисципліна є гуманітарно і педагогічно орієнтованою інтерпретацією регламентованої для вивчення науки "Патології" ("Патологічної фізіології"). В рамках "Патопедагогіки" формуються уявлення про людину в системах взаємодії: "норма патологія", "адаптація - шкільна дезадаптація" "норма - патологія, що виникає чи проявляється в умовах освітнього процесу чи під його впливом", "нормативність - крайові, екстремальні стани і стреси, що формуються в умовах освітнього процесу", "Ноmo Educandus - освітнє середовище і процес взаємодії $з$ нормативними і патологічними наслідками", "ідеальне - реальні освітні умови і фактори ризику", 
"ідеальне, нормативне - нормативні і патологічні зміни, які виникають в освітньому процесі", "сталість зміни", "сталість - процесуальність". Загальні уявлення про "Патопедагогіку" висвітлені нами в журналі "Наукові записки" за 2018 рік (журнал Національного педагогічного університету імені М. П. Драгоманова). В контексті вивчення патології (переважно етиології і патогенезу) на даному рівні актуалізується біомеханіка і дефектологія, а також виокремлено вчення П. Анохіна про функціональні системи, в рамках якого розглядається специфіка патологічних функціональних систем та рухової активності. До цього рівня ми відносимо також усталену дисципліну гігієну.

III. Рівень практично орієнтованих узагальнюючих $i$ методичних дисциплін, які мають свою теоретичну базу та формується на основі фундаментальних (теоретичних) і практично орієнтованих знань. Такою базисною $\mathrm{i}$ "методичною" дисципліною на цьому рівні нами представляється "Пропедевтика здоров'я та профілактики". В рамках даної нової дисципліни (чи точніше дисциплінарно-методичного напряму) визначаються загальні підходи до збереження здоров'я і життя, а також формуються узагальнені та стратегічні уявлення і стратегії профілактики та корекції значимої патології. Вказана дисципліна спрямована на розвиток загальних, інтегративних, цілісних, ціннісних, панорамних і частково конкретизованих (специфікованих) уявлень, знань, розумінь та інтерпретацій здоров'я і значимих для освітнього процесу патологій та факторів і умов їх виникнення, в контексті профілактики. "Пропедевтика здоров’я та профілактики" розкриває уявлення про людину в системах взаємодії: "життя - його збереження", "загальні уявлення про здоров’я - освітні умови збереження здоров’я", "здоров’я - освітні умови і ризики формування патології", "загальні уявлення про здоров'я напрями збереження здоров'я"; "здоров'я - загальні підходи до профілактики патологій", "здоров'я профілактика значимих в освітньому процесі патологій", "здоров’я - корекція значимих в освітньому процесі патологій засобами фізичної культури", "здоров'я - діагностика здоров'я", "здоров'я діагностика значимої патології", "здоров'я - прогноз здоров'я", "здоров'я - прогноз виникнення патології", "патологія - стратегії, умови і фактори іiї попередження", "здоров’я - стратегії, умови і фактори його корекції співвідносно до профілактики порушень", "здоров’я - цінність і етика здоров'я", "здоров'я - інклюзія", "здоров'я - рухова активність і тренувальні режими" та ін. В контексті стратегій використання узагальнених підходів для збереження здоров’я, профілактики, діагностики і корекції на даному рівні вивчаються такі усталені дисциплінарні напрями як: біомеханіка, кінезіологія, інклюзія, дефектологія, а також виокремлено актуалізується вчення П. Анохіна про функціональні системи. На даному рівні розкриваються стратегічні і базисні положення інклюзивної освіти i культури. Актуалізуються загальні аспекти дефектології співвідносно з осмисленням базисних положень інклюзії. Застосовується також валеологія і розроблені в рамках даного напряму загальні підходи до формування здорового способу життя. На цьому рівні актуальними є використання превентивної педагогіки та гігієни.

IV.Рівень практично $i$ технологічно спрямованих дисципліни. "Збереження здоров'я та профілактика" ("Терапія здоров'я") є основною "методичною" дисципліною на даному рівні. Вказана дисципліна безпосередньо спрямована на збереження здоров'я та життя, а також метою їі застосування $\epsilon$ профілактика та корекція (по можливості) конкретних патологій. Вона $є$ "кінцевою" дисципліною на методологічно-проблемній осі "теорія - практика". Дана дисципліна є феноменологічно орієнтованою в широкому розумінні цього терміну. Феноменологія трактується в даному випадку: як спосіб максимально широкої, але разом $з$ тим доцільної та актуальної репрезентації систем необхідних знань і уявлень про певні нормативні і / чи патологічні феномени; як шлях розділення, диференціації певних феноменів; як напрям "феноменологічно" і практично орієнтованої специфікації (конкретизації) діагностичних знань, цінностей, візій і методик та здоров'язбережувальних впливів; як "пізнавальнофеноменологічна" умова формування професійних і темпорально орієнтованих (в часовій розгортці) візій, мислення, рефлексій та розвиток інтелектуально-аналітичних навичок і когнітивних стереотипів спрямованих на прогнозування та розкриття здоров'язбережувальної антиципації (прогнозування i передбачення, які розглядаються як необхідні компоненти професійного мислення і практик збереження здоров’я); як складова розвитку ціннісного ставлення до людини, до її проблем та ситуацій; як візія, що розкриває антропологічну, екзистенційну і кордоцентричну сутність збереження життя і здоров'я; як технологічна і душевна інтенція збереження здоров'я, життя і антропного образу людини та ін.

"Терапія здоров'я" (чи "Збереження здоров'я та профілактика") як "методична дисципліна" розроблена в методологічних рамках медичних традицій, педагогіки здоров’я і превентивної педагогіки. Відмінністю цієї дисципліни від валеології є інші та ширші теоретичні, методичні і світоглядні передумови розробки та сама структура. "Терапія здоров'я" формується, перш за все, на основі класичних медичних принципів, в основі яких лежить ідея не принесення шкоди, мінімізації впливів та їх доказовості, а також максимально можливої об'єктивізації проблем та феноменів, які вивчаються. Здоров'я, як і патологія, розглядається взаємозалежно тому, що патологія розуміється як спосіб адаптації і реагування організму на певну проблему. 
Такі візії особливо є значимими в процесі впровадження інклюзії і відповідно є важливими при формуванні інклюзивно орієнтованих професійних знань, цінностей та установок. В даному напрямі також мінімізовані ілюзії та міфи про те, що нібито за допомогою нагромадження відносно простих чи незвичайних і "не традиційних" впливів ми можемо значно покращити здоров'я чи провести ефективну профілактику. Ця "методична дисципліна" (чи "дисциплінарно-методичний напрям"), яка безпосередньо "переходить" в практики і технології збереження здоров’я, разом з дисциплінами вказаних I, II і III рівнів, $\epsilon$ епістеміологічною і методологічною умовою демаркації здоров'язбережувальних знань і практик сформованих в рамках сучасної наукової парадигми від квазінаукових та "народних", міфів про здоров'я і від шарлатанства.

В контексті специфікованих і практично орієнтованих візій та підходів до збереження здоров'я, профілактики, діагностики і корекції на даному рівні актуалізуються біомеханіка, кінезіологія, інклюзія, дефектологія, а також виокремлено вчення П. Анохіна про функціональні системи; репрезентуються спеціальні підходи, практики і технології впровадження інклюзивної освіти, а також особливості збереження здоров'я в дітей з особливими потребами в умовах освітнього процесу. Вивчаються значимі практично орієнтовані аспекти дефектології співвідносно з інклюзивними знаннями. Використовуються також технології і практики гігієни та превентивної педагогіки.

V. Рівень практичної здоров'язбережувальної діяльності. Вказана діяльність є інтелектуальною i "інструментальною" частиною реалізації здоров'язбережувальної компетентності вчителя фізичної культури, включаючись майже у більшість іiї компонентів: інтелектуально-иіннісний, діяльніснодискурсивний і інклюзивно-гуманістичний. Окрім методик, технологій і практик збереження здоров'я ми виділяємо також освітні досвіди збереження здоров'я сукупно 3 ï аналізом та ціннісною i інтелектуальною рефлексією.

Дисциплінарно-методологічна матриця, як і здоров'язбережувальна компетентність, розроблені нами в концептуально-смислових рамках ідеї освітньої раціональності, сформованої О. Дольською [5]. Вказана матриця є відповідно методологічно орієнтованою репрезентацією загально наукових, дисциплінарних і проблемних аспектів освітньої раціональності. Вчителі фізичної культури в такому випадку розглядаються як носії вказаної раціональності. Даний варіант освітньої раціональності спрямований на збереження здоров'я, ми визначаємо як здоров'язбережувальну раціональність (чи освітню раціональність збереження здоров'я). Здоров'язбережувальна ращіональність формується на основі рецепції та герменевтичної [5: 192-210] і ціннісної рефлексії медичної, педагогічної, гуманітарної та філософської інтелектуальних традицій. Дисциплінарно-методологічна матриця і здоров'язбережувальна компетентність розробляються нами в дусі європейської постнекласичної традиції раціональності, значимою складовою яких є антропологічний, герменевичний [5: 192-210] і подієвий виміри [5: 206$208]$.

Завершуючи розгляд нашої проблематики ми, акцентуючи увагу на значимості для збереження життя дітей інтелектуального, діагностичного і прогностичного аспектів професійної діяльності вчителя фізичної культури, а також концентруючись на важливості актуалізації і розкриття Raio педагога у формі здоров'язбережувальної раціональності згадуємо, давню мудрість про те, що - Mens cuiusque is est cujusqu (Розум кожного - це і є він сам).

Висновки. 1. На основі аналізу освітньої здоров'язбережувальної діяльності вчителя фізичної культури ми актуалізуємо значимість інтегративного розвитку інтелектуальної і ціннісної складових, які лежать в основі діагностичних візій, методик і технологій. Тому традиційний "когнітивний компонент" здоров'язбережувальної компетентності ми визначаємо як "інтелектуально-цііннісний". 2. Використовуючи трансфер медичних, гігієнічних, психологічних і гуманітарних знань, практик, стратегій і цінностей та осмислюючи традиції європейської класичної і постнекласичної раціональності та ii репрезентацію в культурно-освітньому просторі у формі освітньої раціональності, а також враховуючи значимість інтелектуальної складової в збереженні здоров'я дітей ми формулюємо базовий системоорганізуючий методологічний концепт дисииллінарно-методологічної матриці здоров'язбережувальної компетентності вчителя фізичної культури, яка є рівневою, спеціалізованою та інтенціональною системою усталених навчальних дисциплін, проблемно орієнтованих "дисциплінарнометодичних напрямів" та актуальних проблем і тем. 3. В структурі дисциплінарно-методологічної матриці виділяються п'ять якісно відмінних рівнів, кожен з яких "заповнений" певними навчальними дисциплінами та проблемними напрямами. Дана матриця сформована на основі аналізу і інтелектуальноціннісної рефлексії європейських інтелектуальних традицій та ідей європоцентричних реформувань української освіти, а також шляхом осмислення компетентнісної парадигми і концепції освітньої раціональності. 4. Відповідно до методологічного, ціннісно-смислового та інтелектуального полів, визначених дисциплінарно-методологічною матрицею, нами виділяються такі нові дисциплінарні (чи методичні, "методичні дисципліни" чи точніше "дисциплінарно-методичні напрями") напрями: "Патопедагогіка" ("Маргінальна педагогіка"), "Пропедевтика здоров’я і профілактики", "Терапія здоров’я" ("Збереження здоров’я і профілактика". "Патопедагогіка" є гуманітарно орієнтованою інтерпретацією 
медичного напряму "Патологія". Напрям "Пропедевтика здоров’я і профілактики" спрямований на формування панорамних, концептуальних, антропологічно-ціннісних та загальних візій, знань і підходів, які розкривають феномен здоров'я, співвідносно 3 профілактикою і корекцією освітньо значимої патології. Метою напряму "Терапія здоров'я" $\epsilon$ ефективна здоров'язбережувальна діяльність педагога, яка здійснюється на теоретичному базисі практично орієнтованої конкретизації (специфікації) проблематики збереження здоров'я, а також співвідносного розгляду питань феноменології, профілактики і корекції патології. Формуються вказані "дисциплінарно-методичні напрями" на основі трансферу та інтеграції медичних, педагогічних, інклюзивних, дефектологічних, психологічних i гуманітарних знань, методологій, практик, цінностей та стратегій. Використання дисциплінарнометодологічної матриці є ефективними методологічним і епістеміологічним засобами для удосконалення здоров'язбережувальної компетентності вчителя фізичної культури в умовах післядипломної освіти.

6. Знаннєві, методологічно-світоглядні, методичні, герменевтичні та епістеміологічні умови, які задаються дисциплінарно-методологічною матрицею, а також освітня раціональність збереження здоров’я є методологічною основою демаркації здоров'язбережувальних знань і практик, сформованих в рамках сучасної наукової парадигми від квазінаукових і "народних".

Перспективи подальших досліджень. Надалі ми плануємо уточнити і розширити методологічну, навчально-методичну, пізнавальну специфіку та спрямованість рівнів представленої нами "дисциплінарно-методологічної матриці здоров'язбережувальної компетентності вчителя фізичної культури", а також на основі розгляду значимих проблем здоров'я в технологічному контексті проаналізувати транспроблемну, міждисциплінарну і трансдисциплінарну взаємодію між дисциплінами і "дисциплінарно-методичними напрямами" у даній матриці.

\section{СПИСОК ВИКОРИСТАНИХ ДЖЕРЕЛ ТА ЛІТЕРАТУРИ}

1. Аристотель Никомахова этика / Аристотель // Собрание сочинений : в 4 т.. - Москва, 1984. - Т. 4. - С. 53294.

2. Дольская О. А. Трансформации рациональности в современном образовании : [монографія] / О. А. Дольская. - Харьков : НТУ "ХПИ" ; Издатель Савчук О. О., 2013. - 352 с.

3. Комаров С. В. Истоки техн. действие по образцу, случай и фронезис / С. В. Комаров // Вестник Пермского национального исследовательского политехнического университета. Культура. История. Философия. Право. - 2016. - № 2. - С. 79-87.

4. Кремень В. Г. Синергетична модель розвитку освіти як відповідь на виклики сьогодення / В. Г. Кремень // Рідна школа. - 2010. - № 6. - С. 3-6.

5. Огурцов А. П. Дисциплинарная структура науки; ее генезис и обоснование / А. П. Огурцов ; ред. П. П. Гайденко. - Москва : Наука, 1988. - 256 с.

6. Розроблення освітніх програм : метод. рек. / В. М. Захарченко, В. І. Луговий, Ю. М. Рашкевич, Ж. В. Таланова ; за ред. В. Г. Кременя. - Київ : НВЦ "Пріоритети", 2014. - 120 с.

7. Кун Т. С. Структура научных революций / Томас Самюэль Кун ; сост. В. Ю. Кузнецов. - Москва : АСТ, 2003. $-605 \mathrm{c}$.

8. Федорець В. М. Аналіз та актуалізація взаємодії вікових, нервових і локомоторних детермінант кардіологічного здоров'я в контексті формування здоров'язберігаючого підходу / В. М. Федорець // Фізична культура, спорт та здоров'я нації : [зб. наук. пр.]. - Вінниця, 2011. - Вип. 12, т. 3. - С. 137-145.

9. Федорець В. М. Концептуалізація антропологічної моделі здоров'язбережувальної компетентності вчителя фізичної культури / В. М. Федорець // Вісник післядипломної освіти. Серія "Педагогічні науки" : [зб. наук. пр.]. - НАПН України, ДВНЗ "Ун-т менедж. освіти" ; голов. ред. В. В. Олійник. - Київ : Атопол Груп, 2017. Вип. 5 (34). - С. 137-178.

10. Bollnow O. F. Pädagogik in anthropologischer Sicht / O. F. Bollnow. - Tokyo : Tamagawa University Press, 1971. $-80 \mathrm{p}$.

\section{REFERENCES (TRANSLATED \& TRANSLITERATED)}

1. Aristotle Nikomahova ehtika [Nicomachean Ethics] / Aristotle // Sobranie sochinenii : v 4 t. [Collected Works in 4 Volumes] / Aristotle. - Moscow, 1984. - T. 4. - S. 53-294.

2. Dolskaya O. A. Transformatsii ratsional'nosti $v$ sovremennom obrazovanii [Transformations of Rationality in Modern Education] : [monografiia] / O. A. Dolskaya. - Kharkiv: NTU "HPI" ; Izdatel' Savchuk O. O., 2013. $352 \mathrm{~s}$.

3. Komarov S. V. Istoki tehne : deistvie po obraztsu, sluchai i fronezis [The Origins of the "Techne" : the Action According to Eidos, Occasion and Phronesys] / S. V. Komarov / Vestnik Permskogo natsional'nogo issledovatel'skogo politehnicheskogo universiteta. Kul'tura. Istoriia. Filosofiia. Pravo [Bulletin of PNRPU. Culture. History. Philosophy. Law]. - 2016. - № 2. - S. 79-87.

4. Kremen V. G. Synergetychna model' rozvytku osvity yak vidpovid' na vyklyky siogodennia [Synergetic Model of Education Development as a Response to the Challenges of the Present] / V. Kremen // Ridna Shkola [Native School]. - 2010. - № 6. - C. 3-6.

5. Ogurtsov A. P. Distsiplinarnaia struktura nauki : yeie genezis i obosnovaniie [Disciplinary Structure of Science: Its Genesis and Justification] / A. P. Ogurtsov ; red. P. P. Gaydenko. - Moscow : Nauka, 1988. - 256 s. 
6. Rozroblennia osvitnikh prohram [Development of Educational Programs] : metod. rek. / V. M. Zakharchenko, V. I. Luhovyy, Yu. M. Rashkevych, Zh. V. Talanova ; za red. V. H. Kremenya. - Kyiv : NVTS "Priorytety", 2014. $120 \mathrm{~s}$.

7. Kuhn T. S. Struktura nauchnykh revoliutsii [Structure of Scientific Revolutions] / Thomas Samuel Kuhn ; sost. V. YU. Kuznetsov. - Moscow : ACT, 2003. - 605 s.

8. Fedorets V. M. Analiz ta aktualizatsiia vzaiemodii vikovykh, nervovykh i lokomotornykh determinant kardiolohichnoho zdorovia $\mathrm{v}$ konteksti formuvannya zdorov'yazberihayuchoho pidkhodu [Analysis and Updating of the Interaction of Age, Nervous and Locomotor Determinants of Cardiological Health in the Context of Forming a Health-Saving Approach] / V. M. Fedorets // Fizychna kultura, sport ta zdorovia natsii [Physical Culture, Sports and Health of the Nation] : [zb. nauk. pr]. - Vinnytsia, 2011. - Vyp. 12, t. 3. - S. 137-145.

9. Fedorets V. M. Kontseptualizatsiya antropolohichnoyi modeli zdoroviazberezhuvalnoi kompetentnosti vchytelia fizychnoi kul'tury [Conceptualization of the Anthropological Model of Healthcare-Saving Competence of the Teacher of Physical Culture] / V. M. Fedorets // Visnyk pisliadyplomnoi osvity. Seriia "Pedahohichni nauky" [Physical Culture, Sports and Health of the Nation] : [zb. nauk. pr.] / NAPN Ukrainy, DVNZ "Un-t menedzh. osvity" ; holov. red. V. V. Oliynyk. - Kyiv : Atopol Hrup, 2017. - Vyp. 5 (34). - S. 137-178.

10. Bollnow O. F. Pädagogik in anthropologischer Sicht [Pedagogy in Anthropological Perspective] / O. F. Bollnow. Tokyo : Tamagawa University Press, 1971. -80 p.

Федорец В. Н. Концептуализация дисциплинарно-методологической матрицы развития здоровьесохраняющей компетентности учителя физической культуры в условиях последипломного образования.

В статье презентуется методологическая разработка дисииплинарно-методологической матриць развития здоровьсохраняющей компетентности учителя физической культурь в условиях последипломного образования, которая является уровневой и интенциональной системой учебных дисциплин и актуальных проблем. На основе трансфера медицинских знаний в иенностно-смыслових и методологических рамках указанной матрицы нами представляются новые методические (или дисииллинарнье) направления "Патопедагогика" ("Маргинальная педагогика"), "Пропедевтика здоровья и профилактики", "Сохранение здоровья и профилактика". Указанные направления являются гуманитарной и педагогической интерпретацией традиционных медицинских дисциплин.

Ключевые слова: здоровьсохраняющая компетентность учителя физической культуры, методология, методика, трансфер знаний, дисииплинарно-методологическая матрица, дисииплинарная структура, образовательная рачиональность, парадигма.

\section{Fedorets V. M. Conceptualization of the Disciplinary-Methodological Matrix of Development of a Physical Education Teacher's Health Preserving Competence in Conditions of Post-Graduate Education.}

The article presents the methodological development of a disciplinary-methodological matrix of development of a Physical Education teacher's health preserving competence in conditions of post-graduate education. The matrix is a level-based and intentional system of study courses and current issues. On the basis of transfer of medical knowledge new methodic (or disciplinary-methodic) directions are formed. "Pathopedagogics" is a humanitarianly oriented interpretation of the medical field of "Pathology". The field of "Health propedeutics and prevention" is aimed at formation of panoramic, conceptual, general visions, knowledge and approached, which present the phenomenon of health in correlation with prevention and correction of the educationally significant pathology. The purpose of the "Health preservation and prevention" field is the specification of the health preservation problematics, whichis carried out in correlation with pathology prevention and correction.

The following fields are formed on the basis of transfer and integration of medical, inclusive, defectology, psychological and humanitarian knowledge, practice, values and strategies. Application of the disciplinarymethodological matrix is an efficient methodological tool for improving the health preserving competence of a Physical Education teacher in conditions of post-graduate education.

Key words: health preserving competence of a Physical Education teacher, methodology, methodics, transfer of knowledge, disciplinary-methodological matrix, disciplinary structure, educational rationality, paradigm. 